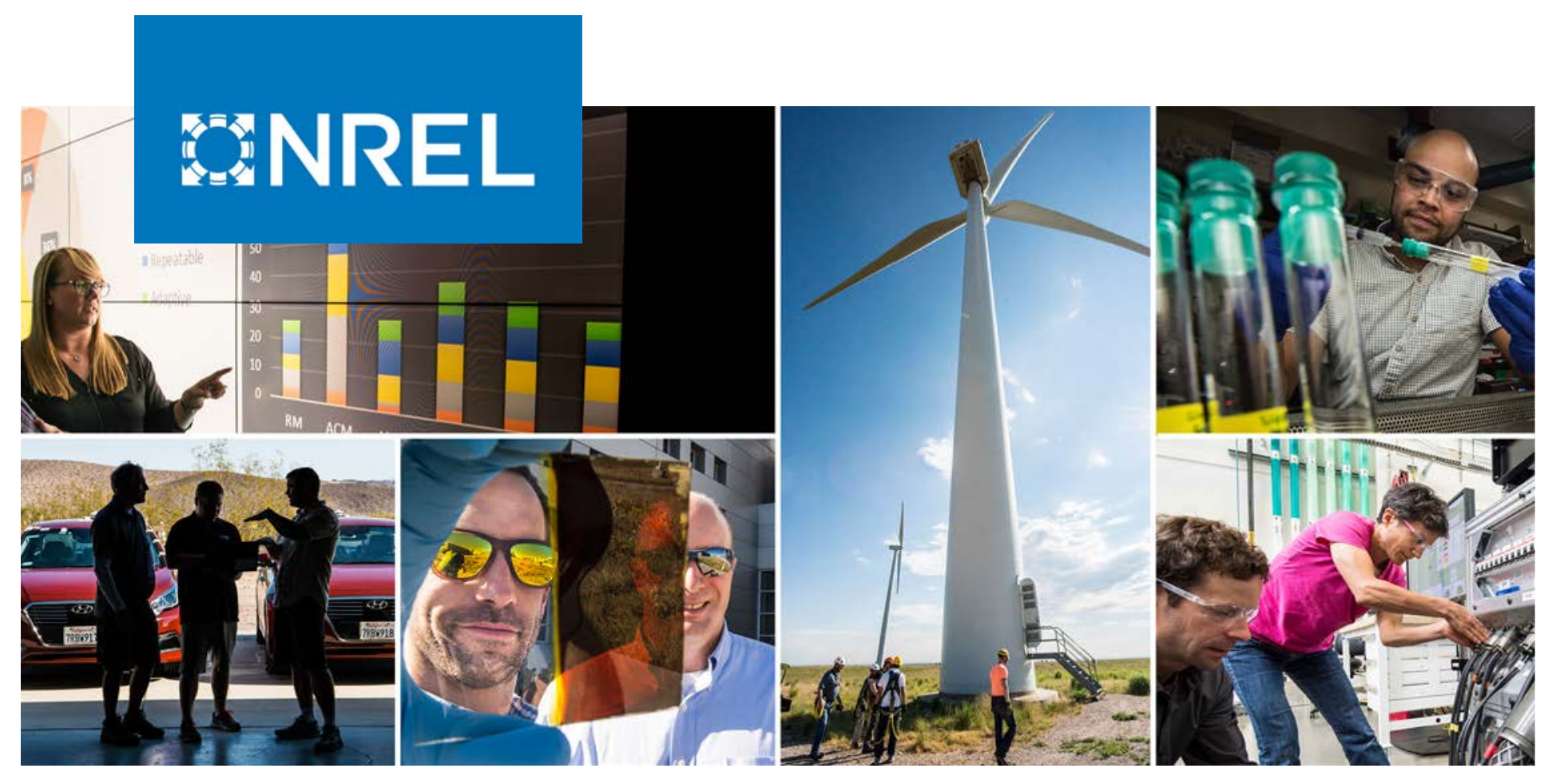

\title{
Igiugig Site Visit Report
}

Levi Kilcher, ${ }^{1}$ Rebecca Green, ${ }^{1}$ Eliza Hotchkiss, ${ }^{1}$ Greg Stark, ${ }^{1}$ AlexAnna Salmon, ${ }^{2}$ and Karl Hill ${ }^{2}$

\section{National Renewable Energy Laboratory \\ 2 lgiugig Village Council}

NREL is a national laboratory of the U.S. Department of Energy Office of Energy Efficiency \& Renewable Energy

Operated by the Alliance for Sustainable Energy, LLC

This report is available at no cost from the National Renewable Energy Laboratory (NREL) at www.nrel.gov/publications.

\section{Technical Report}

NREL/TP-5700-79607

November 2021 


\title{
GNREL
}

\section{Igiugig Site Visit Report}

\section{Levi Kilcher, ${ }^{1}$ Rebecca Green, ${ }^{1}$ Eliza Hotchkiss, ${ }^{1}$ Greg Stark, ${ }^{1}$ AlexAnna Salmon, ${ }^{2}$ and Karl Hill ${ }^{2}$}

\author{
1 National Renewable Energy Laboratory \\ 2 lgiugig Village Council
}

\section{Suggested Citation}

Kilcher, Levi, Rebecca Green, Eliza Hotchkiss, Greg Stark, AlexAnna Salmon, Karl Hill. 2021. Igiugig Site Visit Report. Golden, CO: National Renewable Energy Laboratory.

NREL/TP-5700-79607. https://www.nrel.gov/docs/fy220sti/79607.pdf.

NREL is a national laboratory of the U.S. Department of Energy Office of Energy Efficiency \& Renewable Energy Operated by the Alliance for Sustainable Energy, LLC

This report is available at no cost from the National Renewable Energy Laboratory (NREL) at www.nrel.gov/publications.

Contract No. DE-AC36-08GO28308
Technical Report NREL/TP-5700-79607 November 2021

National Renewable Energy Laboratory 15013 Denver West Parkway Golden, CO 80401 303-275-3000 • www.nrel.gov 


\section{NOTICE}

This work was authored [in part] by the National Renewable Energy Laboratory, operated by Alliance for Sustainable Energy, LLC, for the U.S. Department of Energy (DOE) under Contract No. DE-AC36-08GO28308. Funding provided by the U.S. Department of Energy Office of Energy Efficiency and Renewable Energy Water Power Technologies Office. The views expressed herein do not necessarily represent the views of the DOE or the U.S. Government.

This report is available at no cost from the National Renewable Energy Laboratory (NREL) at www.nrel.gov/publications.

U.S. Department of Energy (DOE) reports produced after 1991 and a growing number of pre-1991 documents are available free via www.OSTI.gov.

Cover Photos by Dennis Schroeder: (clockwise, left to right) NREL 51934, NREL 45897, NREL 42160, NREL 45891, NREL 48097, NREL 46526.

NREL prints on paper that contains recycled content. 


\section{Foreword}

This report was originally drafted during the spring and summer of 2019 , following a site visit to Igiugig, Alaska. It is being published now, with only minor updates to account for the deployment and operation of Ocean Renewable Power Company's RivGen turbine, to provide a public record of the site visit and its outcomes. The report has not been updated to include a detailed account of the RivGen project, because that work is the subject of ongoing research and development and is beyond the scope of the National Renewable Energy Laboratory's role in the project. 


\section{Acknowledgments}

The National Renewable Energy Laboratory staff would like to thank the Igiugig Village Council for helping to arrange logistics and hosting the team, along with other stakeholders and partners from around Alaska and the country during their visit January 23-25, 2019. The assistance of AlexAnna Salmon, Christina Salmon, and Karl Hill was essential to the success of the site visit. Other Igiugig residents, Igiugig Village Council staff, the teachers and students at the school, and many more were actively engaged and contributed to the site visit activities. The U.S. Department of Energy's Water Power Technologies Office provided support for this project. Quyana! 


\section{Executive Summary}

The National Renewable Energy Laboratory (NREL) team conducted a site visit January 23-25, 2019, with the Igiugig Village Council (IVC) and other stakeholders to assist the community of Igiugig in refining its long-term energy strategy. The agenda included a tour of the village, data collection, presentations by stakeholders, long-term vision exercises, examination of energy scenarios, and a workshop with high-school students. Participants in the site visit activities represented industry as well as local, regional, and government organizations. There were 24 attendees at the all-day community workshop on January 24 with participants from the IVC, NREL, Bristol Bay Native Association, Bristol Bay Native Corporation, Lake and Peninsula Borough, Alaska Energy Authority, Intergrid, Ocean Renewable Power Company, Deer Stone Consulting, Southwest Alaska Municipal Conference, and University of Alaska Fairbanks's Alaska Center for Energy and Power.

Igiugig is a small, well-organized, rural Alaskan community with a leadership team that has broad community support. The use of consensus-based decision making is one example of how the leadership team actively promotes community-focused thinking. The NREL team observed anecdotal evidence of how this approach is strengthening the community: active participation in the visioning exercise, a student-hosted fundraiser dinner at the school, a clean and organized landfill, and well-maintained roads and buildings.

Igiugig has wind, solar, and river hydrokinetic resources readily available within the community. Wind has shown to be a promising energy resource in the region and has been integrated into microgrids around the state, but the community has had mixed success with wind energy technologies. The economics of solar energy are improving in Alaska, and economical solar power projects are being installed around the state. Considering that economic activity in Igiugig peaks during the summer sportfishing season, solar power could prove to be a valuable supplement to the electrical system. Igiugig has been a test site for two different river hydrokinetic energy devices, and a third project is underway to operate Ocean Renewable Power Company's RivGen device, which is delivering valuable device performance data, operation and maintenance experience, and design refinement information. As of this writing this device has made over 17.7 million revolutions and delivered over 26.5 megawatthours of power to the community. Igiugig's river resource is fairly unique in Alaska because it is available year-round and has the potential to provide reliable base-load power for months at a time.

A preliminary investigation into the diverse energy resource mix available to the community suggests that Igiugig could achieve very high levels ( $70 \%$ or more) of annual renewable energy generation contributions. A critical first step in pursuing this path is completing energy-efficiency and conservation measures, which has been a primary focus for many years. It is also important to assess the mix of energy assets (generation and storage) that best meets the community's needs, goals, and budget. The early steps taken in a community's grid-modernization efforts determine which options are economical at later stages, so a technical and economic analysis now can guide the most promising path forward. These analyses are most accurate and informative when they are based on actual technology performance and cost data. As the RivGen project continues to operate and generate these data, we will be better prepared to evaluate the technology's long-term viability and identify research areas that would improve it.

Igiugig's energy projects are at the cutting edge of two intersecting technology areas: (1) the deployment of an operational river hydrokinetic turbine, and (2) the integration of renewable energy sources into a microgrid to achieve a very high percentage of renewable energy. If these projects are successful, the lessons learned and technologies developed could help transform microgrids around the world. Igiugig's unique resource mix makes it an ideal location for this work, and the community's organizational 
strength makes it an ideal partner for this ground-breaking work. Ongoing support for technical assistance to manage and address technical challenges along the way will maximize the probability of project success. 


\section{Table of Contents}

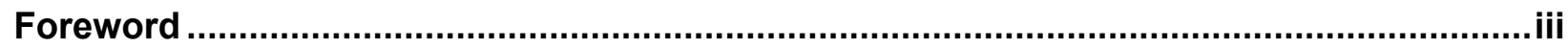

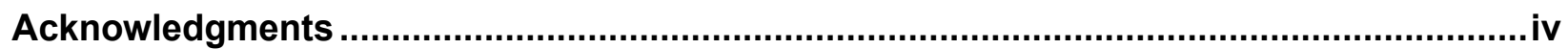

Executive Summary ..............................................................................................................

Table of Contents ................................................................................................................

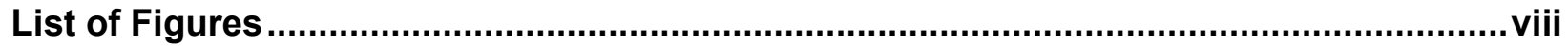

List of Tables ........................................................................................................ vii

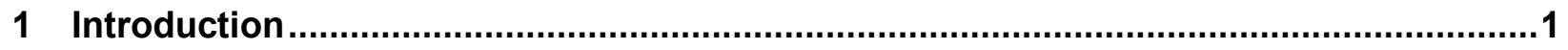

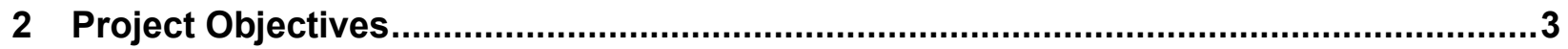

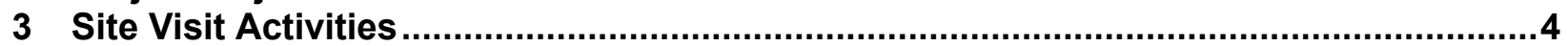

4 Igiugig Village Council and Partner Presentations..................................................

5 Long-Term-Vision Exercise Outcomes......................................................................

6 Prioritized Energy Scenarios ……........................................................................11

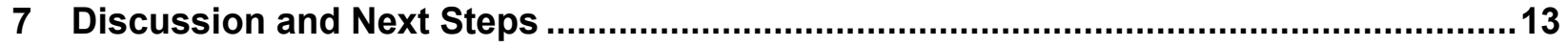

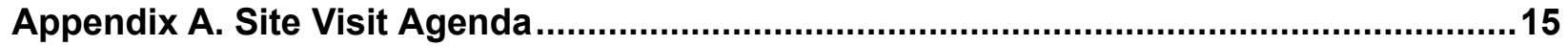

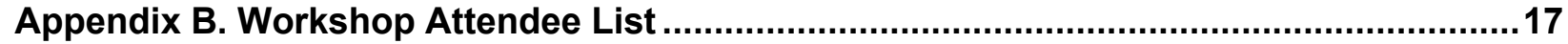

Appendix C. Igiugig Energy History and Goals .........................................................18

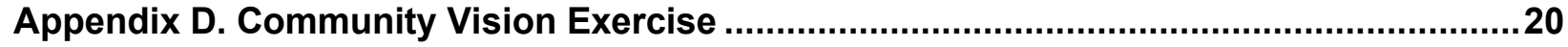

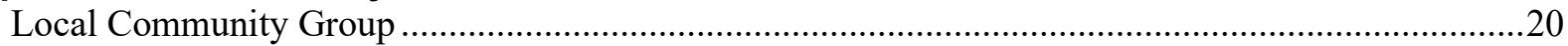

External Stakeholders Group ……………………………………………………………....22 


\section{List of Figures}

Figure 1. Map of Igiugig, Alaska, showing the older, downtown part of the village near the landing strip and newer part of the village further south on Native Corporation land. Image courtesy of Google 1

Figure 2. Several small wind turbines are installed near the Igiugig village greenhouse, with Skystreams visible in the distance and a vertical-axis wind turbine in the foreground. Photo by Rebecca Green, NREL

Figure 3. Members of the site visit team stand on the airport runway in Igiugig. Photo courtesy Karl Hill, IVC.

Figure 4. A tour of the greenhouse was led by Christina Salmon, with a group photo taken next to the greenhouse with Skystream wind turbines in the background (left) and a photo of Christina Salmon speaking inside the greenhouse (right). Photos by Greg Stark, NREL

Figure 5. Dave Hostetter led tours of the water filtration plant (left) and power plant with its three diesel generators (right). Photos by Greg Stark (left) and Rebecca Green (right), NREL6

Figure 6. Community members engage in a long-term-vision exercise for the village (left), with AlexAnna Salmon presenting the overall outcomes from the discussion (right). Photos by Greg Stark, NREL

\section{List of Tables}

Table 1. Electrical Generation Assets Currently Installed.

Table 2. Renewable Energy and Storage Scenarios Identified.

Table A-1. Agenda for Day One - Wednesday, January 23, Noon-4 p.m.

Table A-2. Agenda for Day Two - Thursday, January 24, 10 a.m.-6 p.m.

Table A-3. Agenda for Day Three - Friday, January 25, 9 a.m.-Noon .

Table B-1. Workshop Attendee Information 


\section{Introduction}

The village of Igiugig is a small community (population: 69) located in southwestern Alaska, where Lake Iliamna pours into the Kvichak River. The village is in the Lake and Peninsula Borough and is accessible by airplane year-round or by boat in the summer (Figure 1). The closest villages are more than 40 miles away. The Kvichak River and Lake Iliamna are important resources for the community, especially for the abundant salmon they provide. Sockeye salmon, rainbow trout, and other fish populations support a summertime sportfishing industry, which brings valuable tourism to the village every year. September is also prime caribou, moose, and spruce hen hunting season. The community lies at the intersection of the historical place of three major Alaska Native groups-Yup'ik, Alutiiq, and Athabascan-and residents claim a largely mixed heritage, but the primary language is the Lake Iliamna dialect of Yup'ik. The community embraces a subsistence way of life, which supports a governance system that is based on core cultural values.

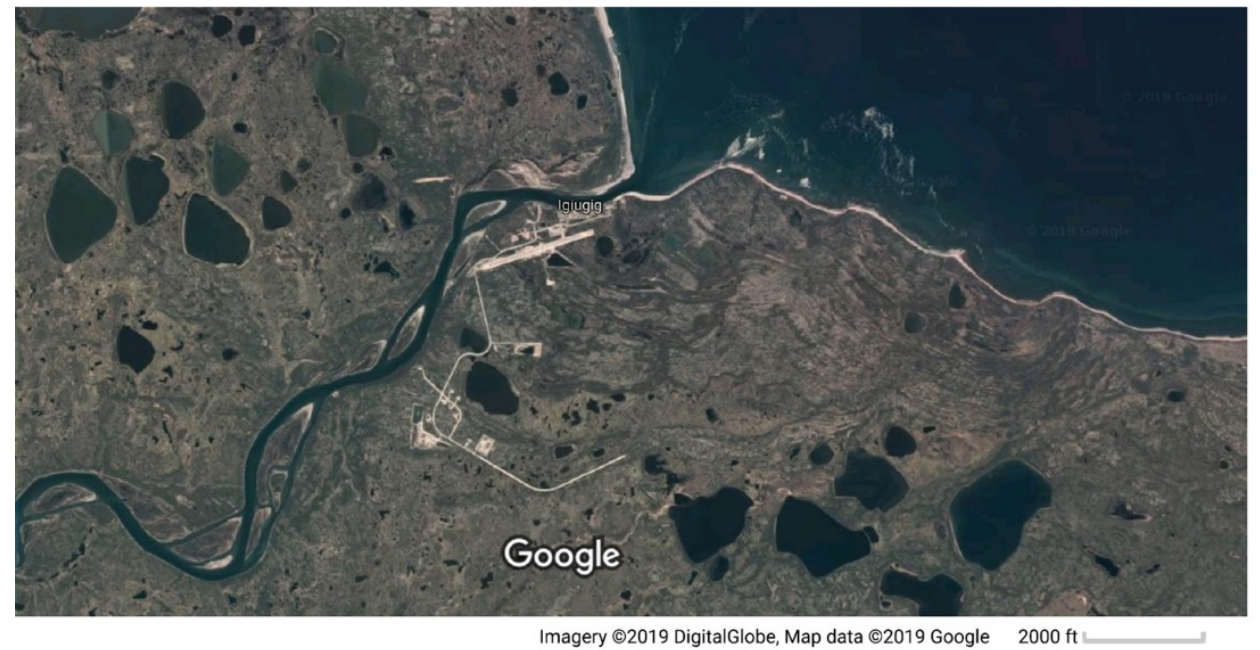

Figure 1. Map of Igiugig, Alaska, showing the older, downtown part of the village near the landing strip and newer part of the village further south on Native Corporation land. Image courtesy of Google

The Igiugig Village Council (IVC), also known as the Tribal Council, is the primary leadership institution in the community and is responsible for handling the governmental activities of the village. IVC's mission is to provide resources, programs, and infrastructure to enhance the residents' quality of life and support the community as a self-sufficient village with strong cultural and environmental values. As a community, Igiugig residents have set the following goals: (1) establish sustainable, social, and economic development that is compatible with their subsistence way of life, (2) invest in life-long education, (3) provide a safe, welcoming community that offers affordable living and a strong, diversified local economy, and (4) maintain good working relationships with other communities, lodges, and state, federal, and local agencies.

The people of Igiugig have been working for many years to achieve energy efficiency and renewable energy goals. Comprehensive community planning began in 2000 and has resulted in a variety of projects, analyses, and reports. In 2010, the IVC adopted an Energy Efficiency and Conservation Strategic Plan developed for the village as part of the U.S. Department of Energy (DOE) Energy Efficiency and Conservation Block Grant Program. In 2013, the National Renewable Energy Laboratory (NREL) worked together with the IVC to perform an energy efficiency and renewable energy site 
assessment for Igiugig with support from DOE's Technical Assistance Program. IVC has been working with regional, state, and federal partners to determine which renewable energy technologies are most viable for its location, including wind, solar photovoltaics (PV), and solar thermal, hydrokinetic, and biomass boilers. A subset of these technologies is currently being used in the village (Figure 2) with varying levels of success (Table 1). Recognizing the value of its unique position at the headwaters of the Kvichak river, Igiugig's leadership has encouraged hydrokinetic turbine developers to test devices in the river near their village. The most successful of these technologies, the Ocean Renewable Power Company's (ORPC's) RivGen turbine, moved forward with an operational test deployment during the summer of 2019. Prior to deployment, the RivGen turbine was estimated to have a $68 \%$ capacity factor in Igiugig if the system were integrated with a battery energy storage (BES) system that enables turning the diesel generators off. In the meantime, the system is providing valuable data on device performance in real-world conditions.

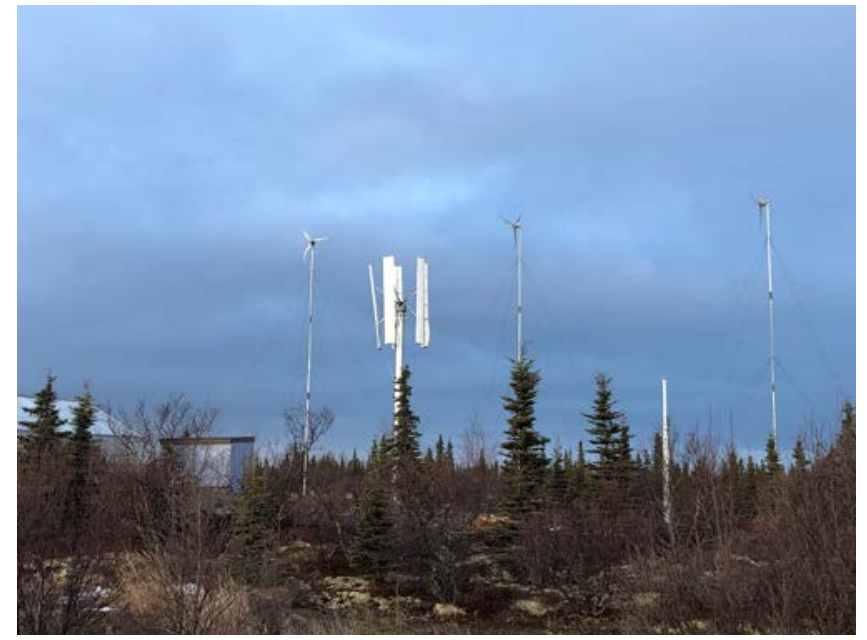

Figure 2. Several small wind turbines are installed near the lgiugig village greenhouse, with Skystreams visible in the distance and a vertical-axis wind turbine in the foreground. Photo by Rebecca Green, NREL

Table 1. Electrical Generation Assets Currently Installed

\begin{tabular}{|l|l|l|}
\hline $\begin{array}{l}\text { Asset } \\
\text { Diesel Generators }\end{array}$ & Three diesel generators at 65 kilowatts (kW) each & \multicolumn{1}{|c|}{ Fescription } \\
\hline $\begin{array}{l}\text { Solar PV } \\
\text { Wind Turbines - } \\
\text { Horizontal Axis }\end{array}$ & \begin{tabular}{l} 
Six 2-kW solar PV (Hostetter and Alvarez residences) \\
\hline $\begin{array}{l}\text { Wind Turbines - } \\
\text { Vertical Axis }\end{array}$
\end{tabular} & $\begin{array}{l}\text { Two 2-kW wind turbines by Wing Power Energy located near the mouth of } \\
\text { the river at fish camp (University of Alaska Anchorage and Stanford research } \\
\text { program); these have required manual supervision to operate. The } \\
\text { greenhouse unit is old and not functional. }\end{array}$ \\
\hline
\end{tabular}




\section{Project Objectives}

The motivation for this project was initially conceived at the Alaska National Lab Day Summit in Fairbanks in the spring of 2018. Leaders from the state of Alaska, DOE, and NREL identified a common goal to better understand how the government can effectively mobilize research and deployment of marine energy technologies to help communities in rural Alaska. This included the need to understand how rural communities in Alaska make energy-related decisions and which factors are considered most important. With these objectives in mind, the DOE Water Power Technologies Office identified the village of Igiugig as an ideal case study and moved forward with sponsoring this project. Igiugig is particularly attractive because of its interest in and proximity to riverine energy resources. Based on this background, this project has two primary goals:

1. To provide DOE with a better understanding of energy-related decision making in a rural, Alaskan, diesel-microgrid community

2. To assist Igiugig in refining its long-term energy strategy.

The purpose of this site visit report is to: (1) summarize the opportunities and challenges for a hightotal-percent renewable energy contribution to Igiugig's power grid, (2) provide a list of renewable energy generation scenarios that could meet the community's goals, and (3) describe the process and factors that shape the community's decisions in formulating a long-term energy strategy. In late 2018, an NREL team began working with the IVC and other stakeholders to establish a site visit agenda. During this site visit, the team had multiple objectives, including to:

- Work with the community to codevelop a long-term vision for the next 10-20 years

- Collect data to better understand energy loads and other power requirements

- Brainstorm renewable energy scenarios in line with the community's vision

- Develop and prioritize a set of scenarios for a more-detailed follow-on analysis. 


\section{Site Visit Activities}

The team held several planning calls leading up to the site visit to identify background materials and define a site visit agenda that would best accomplish the project's goals. Participants on these calls included DOE, NREL, IVC, ORPC, Intergrid LLC, Alaska Energy Authority (AEA), and the University of Alaska Anchorage. The team identified existing energy use and resource data sets for the village, as well as prioritized data gaps for further information collection. The site visit was held in Igiugig January 23-25, 2019 (Figure 3). The agenda included a tour of the village, data collection, presentations, longterm-vision exercises, energy scenario identification, and a school presentation (Appendix A).

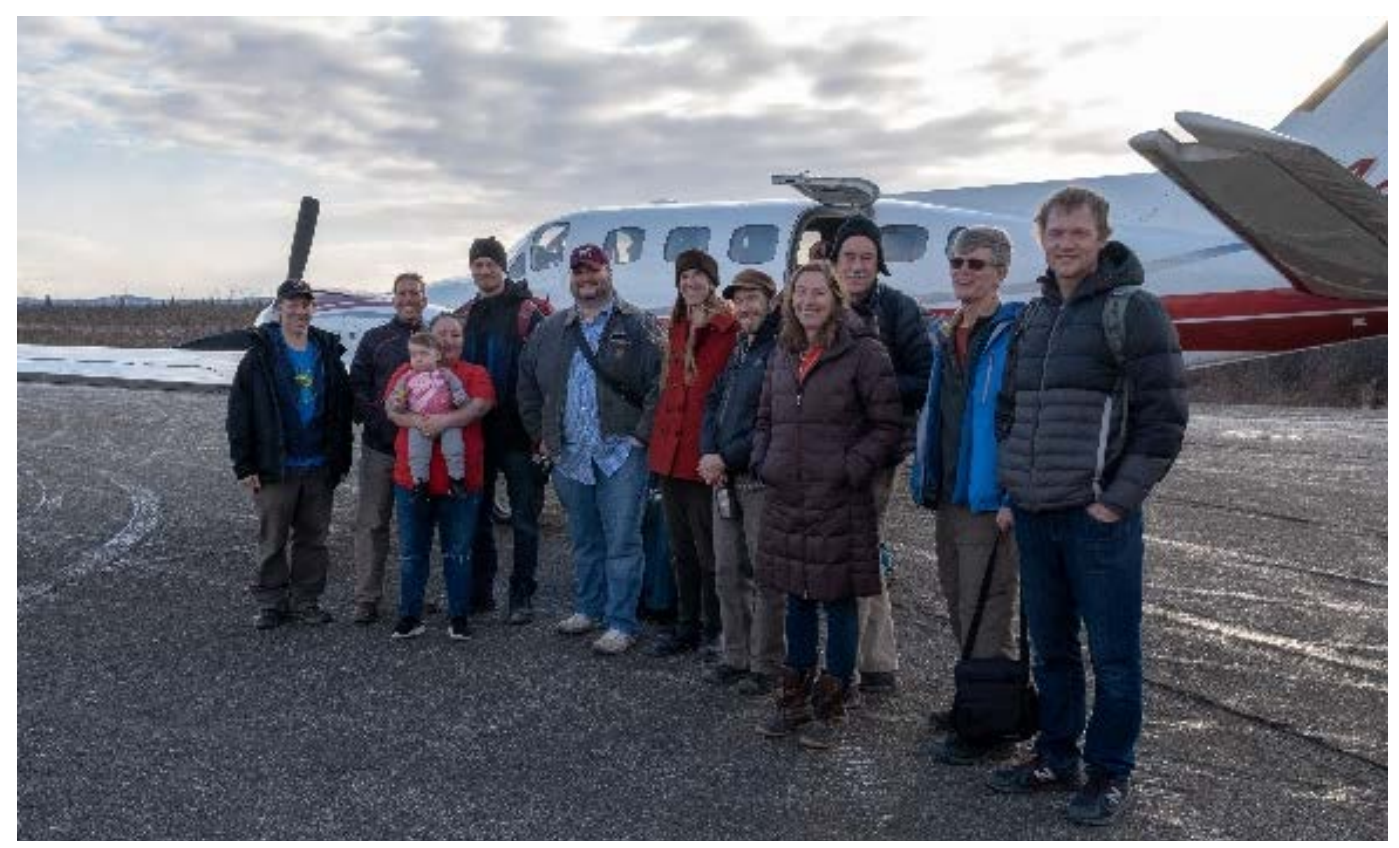

Figure 3. Members of the site visit team stand on the airport runway in Igiugig. Photo courtesy Karl Hill, IVC

Participants in the site visit activities represented industry as well as local, regional, and government organizations. There were 24 attendees at the all-day community workshop on January 24 (Appendix B). From the IVC, AlexAnna Salmon (president), Karl Hill (vice president), and Christina Salmon (council member) presented materials for the village and engaged in discussion with input from numerous community members. The NREL team included Levi Kilcher, Rebecca Green, Eliza Hotchkiss, and Greg Stark. Other external stakeholder participants included Patty Heyano and Jayne Bennet (Bristol Bay Native Association), Daniel Cheyette (Bristol Bay Native Corporation), Danica Wilson (Lake and Peninsula Borough), Josh Craft (Alaska Energy Authority), Rob Wills (Intergrid), Monty Worthington (ORPC), Brian Hirsch (Deer Stone Consulting, attending on behalf of the Southwest Alaska Municipal Conference and Lake and Peninsula Borough), and Jeremy VanderMeer (University of Alaska Fairbanks's Alaska Center for Energy and Power).

On the first day of the visit, IVC leadership provided attendees with an informative tour of the village. Igiugig extends roughly 1.5 miles from the center of town ("the old town") near the airstrip to an outer part of town ("the new town") (Figure 1). Much of the old town is built on Native allotments, except for the airport, which is on Federal-Aviation-Administration-owned land; the new town is primarily on Native Corporation land. Village buildings in the old town include a hangar, store, church, K-12 school, powerhouse, water filtration plant, and residential housing. In the new town, facilities include the health 
clinic, greenhouse, village landfill, and residential housing. The greenhouse extends the growing season by approximately 2 months and provides enough produce for the community for most of the summer (Figure 4). The community actively involves the school in greenhouse operations and sells produce to lodges and neighboring communities during the harvest. The community is generally happy with the current size of greenhouse operations but is open to expansion. The village manages seven rental homes in the community. Sportfishing brings many visitors to the village every summer (150-200 people per day), who stay in campsites and lodges in the area, including Igiugig, Alaska Sportsman's, Seasons on the Fly, Kvichak, and Big Ku Lodges.
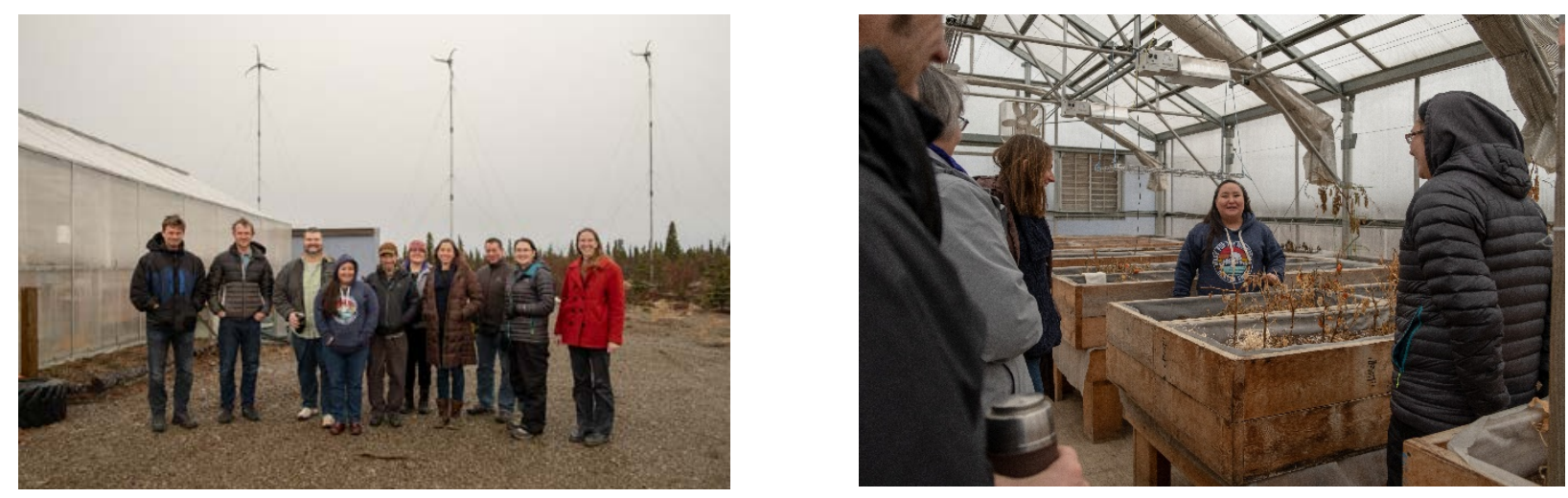

Figure 4. A tour of the greenhouse was led by Christina Salmon, with a group photo taken next to the greenhouse with Skystream wind turbines in the background (left) and a photo of Christina Salmon speaking inside the greenhouse (right). Photos by Greg Stark, NREL

The team conducted a variety of activities to collect data on energy usage and requirements during the site visit. Sandy Alvarez (council member, village electric coordinator and director of accounting) provided records of the village's electrical and fuel consumption dating back to 2012. The community health clinic was identified as one of the biggest energy users in the village. Dave Hostetter (village power and water plant operator) led discussions at the powerhouse and water filtration plants on energy usage and the status of operations (Figure 5). There are currently three 65-kilowatt $(\mathrm{kW})$ diesel generators in the powerhouse, responding to average village loads of $25-30 \mathrm{~kW}$ in summer and $75-80 \mathrm{~kW}$ in winter. In addition, diesel is used for various other purposes throughout the village, including firing boilers in the water treatment plant and fueling stoves for heat in many residences. Currently, the heat recovery loop from the diesel powerhouse extends only to the water treatment facility, water tank, and store. During a tour of the powerhouse, the team had a lengthy discussion regarding the fact that reducing diesel generator use will require a heat source replacement for the recovered heat that currently keeps the water tank from freezing. In terms of renewable energy, Dave Hostetter's house has solar panels and tubes, Sandy Alvarez's house has solar tubes and one Skystream wind turbine, and there are also Skystream wind turbines near the greenhouse (two of the six of which are currently operational; Figure 2 and Table 1). The lodges operate on their own power systems, which are separate from the village (and some of them have begun incorporating solar PV). 

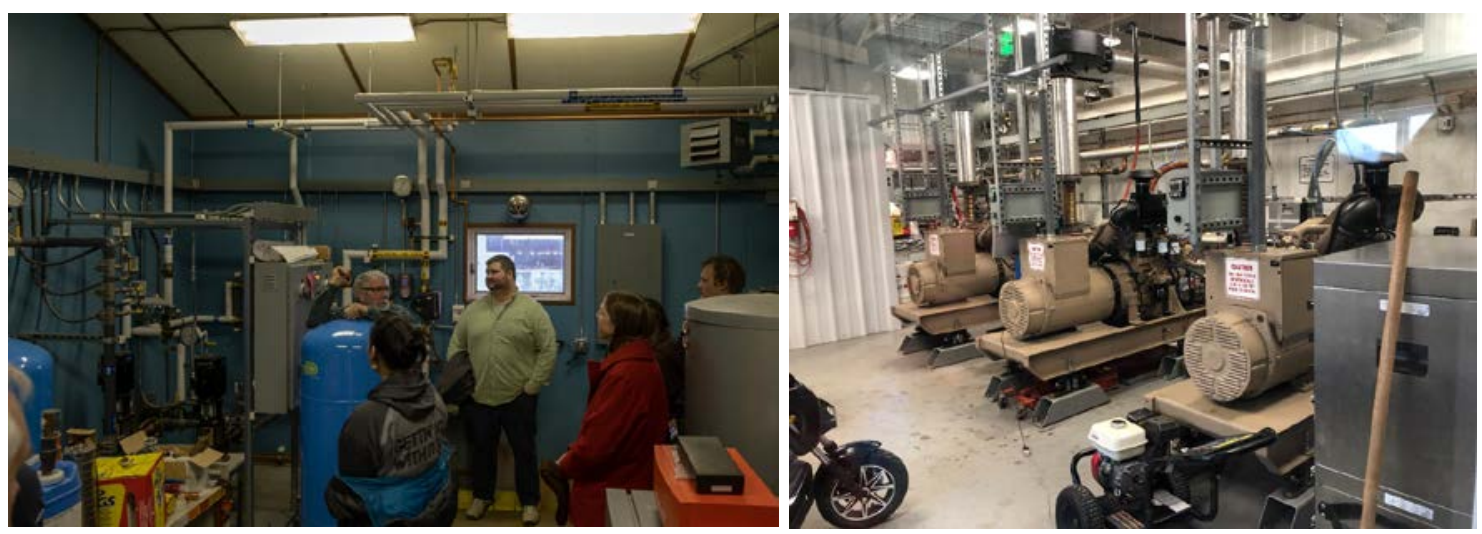

Figure 5. Dave Hostetter led tours of the water filtration plant (left) and power plant with its three diesel generators (right). Photos by Greg Stark (left) and Rebecca Green (right), NREL 


\section{Igiugig Village Council and Partner Presentations}

AlexAnna Salmon and Karl Hill, leaders on the IVC, gave a presentation on Igiugig's energy history, goals, and resources. Additionally, they provided a handout that summarized notable points in each of these areas (Appendix C). The village was previously involved in significant community and energy planning activities in 2000 and 2008, so roughly a decade later, this project comes at an opportune time to develop a more targeted strategic energy plan. The following are highlights from IVC's presentation:

- In 2014, NREL performed energy-efficiency audits for the majority of the village's community buildings. Many recommendations from those audits have been implemented. For example, all U.S. Department of Housing and Urban Development (HUD) home boiler systems were replaced with high-efficiency heating stoves, which resulted in significant savings for residents. New construction followed the provision of energy standards in the NREL report, with two new homes built to align with those higher standards that use Energy Star appliances. Additionally, the lighting in the airplane hangar was switched to light-emitting diodes (LEDs). The water treatment plant was upgraded, and a home identified in the report as "Stacy's home" was weatherized. Several of the recommendations in the report still need to be implemented, including completion of renewable energy installs, like solar PV and wind turbines. Furthermore, the rental homes need to have cold weather stripping installed, all lighting should be changed to LEDs throughout the tribal buildings, and the washeteria needs upgrades (e.g., water conservation measures, lighting, and so on). In general, the community appears to have done an excellent job of prioritizing the most pressing projects. Moreover, new homes are being built to five-star-plus standards (out of six stars in Alaska's Building Energy Efficiency Standards), and the new community center is planned to be a net-zero energy building.

- An overall goal of the community is to achieve energy self-sufficiency by deploying a variety of renewable energy sources to provide a high contribution of renewable power and reduce diesel fuel usage. This goal is in line with the community's core values of encouraging environmental sustainability and mitigating environmental issues, including potential impacts to the highly valued local salmon populations associated with the transport and storage of large quantities of diesel fuel. The village has access to wind, solar, water, and land resources that could all apply to renewable energy build-out scenarios. Land owned by the Native Corporation, such as in the new town, is available to the village for new project development.

- In terms of wind resources, wind data were collected October 2011-October 2012, with the wind resource assessment completed by Knight Piesold. The AEA Wind Program performed an initial feasibility analysis in support of the Igiugig Renewable Energy Fund project. The 2012 meteorological tower study showed an average annual wind speed of 5.8 meters per second $(\mathrm{m} / \mathrm{s})$ at $33 \mathrm{~m}$ above the ground, which corresponds to wind power Class 4 . There is also additional wind resource data from multiple historical records (including the Federal Aviation Administration weather station), so accurate estimates of wind power production are possible. Average wind speeds vary from $5 \mathrm{~m} / \mathrm{s}$ in July and August to $8.5 \mathrm{~m} / \mathrm{s}$ in February. Because of the cubic relation of wind speed and power, winter energy production will be 4-5 times higher than in summer. This aligns well with the annual load profile and points to the potential value of a solar-PV-wind hybrid microgrid.

- In terms of riverine resources, the community has previously established itself as a test bed for river hydrokinetic turbines. The deployment of ORPC's RivGen device during the summer of 2019 was designed to demonstrate reliability and operation and maintenance procedures and to 
document the impact of the device on fish and smolt migration. An important resource has also been the community's many partners who helped with various activities, including project permitting and grant applications, and who could possibly contribute to future development of an energy department or team in the village.

- IVC explained that decision-making in the community operates on a consensus model, including for energy-related decisions: for new ideas, the IVC first brings the whole community together, educates residents on the issues, and polls them. If the entire community is in favor of the proposed action, the IVC will ultimately pass a resolution to take action, but only if $100 \%$ consensus is achieved first. The first round of community discussions always includes sessions with elders, kids, and anyone else who is interested in participating. In cases where consensus has taken a while to achieve, such as the establishment of a local company (e.g., the Iliamna Lake Contractors), the community exercises patience and continues to wait until consensus is achieved, even if it means that action in moving forward takes longer.

A variety of partners and stakeholders also gave presentations to provide context on the latest renewable energy plans and projects in the community. NREL staff discussed the overall goals for the site visit, defined sustainability, resiliency, and food-and-water-nexus concepts and their importance in strategic planning, and discussed combining renewable energy sources and batteries into microgrids in rural Alaska communities. Josh Craft from AEA discussed considerations for renewable energy scenarios unique to Igiugig's needs and the various programs available to the village, including technical assistance, training, and financial loans for potential projects. Rob Wills from Intergrid described his work with microgrids dating back to the 1980s and various projects in Igiugig that started in 2016, including the deployment of small wind turbines, the development of an inverter for integrating renewable energy into Igiugig's grid, and the new wind resource assessment he currently leads. Representing ORPC, Monty Worthington described the company's work in Igiugig since 2014 with DOE funding for the RivGen project and the company's plans for operational deployment during the summer of 2019. The intent was to operate the device for a full calendar year to observe winter's impacts on operating and to collect data on the smolt out-migration. Finally, Jeremy VanderMeer with the Alaska Center for Energy and Power discussed the MiGRIDS software for modeling islanded microgrids and results from performing an electrical energy storage sizing study for Igiugig. 


\section{Long-Term-Vision Exercise Outcomes}

As part of the workshop, presenters conducted a long-term-vision exercise for Igiugig with the primary intent of understanding the community's goals for the next 10-20 years. The following draft energy vision was developed through discussions between the village and stakeholders:

Igiugig's Energy Vision is to improve energy self-sufficiency using local, renewable resources and village workforce with the goal to minimize environmental impact and maintain cultural identity.

The group was split into community members and external partners to gain two different perspectives. Each group was led through a facilitated brainstorming exercise to identify current challenges, long-term vision, and specific solutions for the village. The groups brainstormed within the context of a holistic, strategic-planning framework that included several different sectors. The sectors were selected as a result of the goals of Igiugig leadership to reduce diesel fuel use while protecting the environment and maintaining strong cultural values that affect considerations of infrastructure (e.g., energy, water, transportation, communications, and information technology), the economy, the environment, and social and cultural identity.

After brainstorming, each community member voted on the ideas most important to them to help develop priorities (Figure 6). The challenges that received the highest votes included regional mining, shortage of personnel and expertise in the community, and lack of affordable, energy-efficient housing. The visions that received the highest votes included living by cultural values (e.g., invigorating the Yup'ik dance group, reviving the Yup'ik language, and establishing cultural tourism), running a rock quarry for economic development, and establishing a community where children want to return after attending college. Notably, the community also identified a vision of serving as a regional leader and test bed for renewable energy technologies. Finally, the solutions that received the most votes included deploying a combination of renewable energy sources and storage to achieve energy self-sufficiency, building attractive and affordable housing, continuing an annual local food challenge, planning with youth for a long-term vision, establishing creative land leasing, and developing a water bottling business. The full list of ideas is provided in Appendix D.
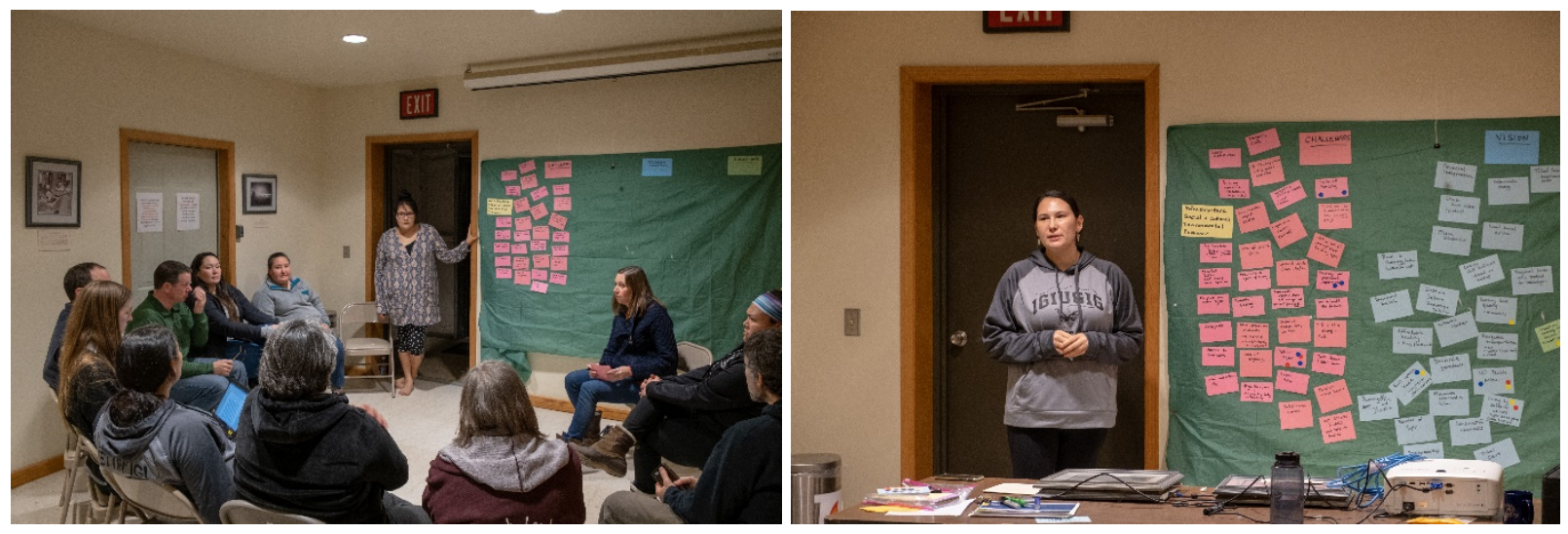

Figure 6. Community members engage in a long-term-vision exercise for the village (left), with AlexAnna Salmon presenting the overall outcomes from the discussion (right). Photos by Greg Stark, NREL

The external partners brainstormed in a separate group. The highest priority challenges for the community identified by this group included capacity limitations related to small community size, internet access, transient loads, oil-spill concerns, transport logistics, economics, and project success. 
For the full list, see Appendix D. External partners felt that developing and executing a holistic community plan to create a resilient and sustainable community should be a top priority. This plan would increase energy self-sufficiency and economic sustainability, account for cultural values, and minimize environmental impact and use of diesel. The overall solution identified was to build a diverse, renewable energy microgrid using a local or regional workforce as much as possible.

Staff from NREL and AEA also spoke to students at the village school to gain their perspectives on what they would like to see in their community in the future. The majority of students indicated they would like to protect the environment and have a healthy wildlife population including salmon and trout, mirroring the goals of the IVC leadership to sustain traditional values. The classroom teacher indicated that there might be interest in a renewable energy theme at the next Goose Camp (in late April). 


\section{Prioritized Energy Scenarios}

Several members of the community and partners reconvened on the final day of the site visit to brainstorm various renewable energy scenarios, prioritize scenarios for detailed economic analysis, and identify remaining data needs. Consideration was given to a combination of renewable energy and storage technologies, including river hydrokinetic turbines (i.e., RivGen), small wind turbines, solar PV and thermal, and BES. Several of these scenarios considered integration with smaller diesel generators than the ones currently being used in the village, given an opportunity to optimize diesel generator size with the addition of new renewable energy sources. The renewable energy and storage scenarios are summarized in Table 2 .

\section{Table 2. Renewable Energy and Storage Scenarios Identified}

\begin{tabular}{|c|c|}
\hline Scenario & Factors To Include \\
\hline Baseline & $\begin{array}{l}\text { Three diesel generators at } 65 \mathrm{~kW} \text { each, } 1.2-\mathrm{kW} \text { solar } \mathrm{PV} \text {, six } 2-\mathrm{kW} \text { wind } \\
\text { turbines, a biomass boiler, a heat recovery loop from the powerhouse } \\
\text { to water treatment facility/water tank/store, solar thermal for heating } \\
\text { applications, greenhouse }\end{array}$ \\
\hline $\begin{array}{l}\text { Scenario } 1 \text { projects currently in the } \\
\text { pipeline) }\end{array}$ & $\begin{array}{c}\text { Diesel generators (two existing at } 65 \mathrm{~kW} \text { ), a } 35-\mathrm{kW} \text { RivGen hydrokinetic } \\
\text { turbine, and 53-75 kilowatt-hours (kWh) of BES }\end{array}$ \\
\hline Scenario 2 (RivGen and wind) & $\begin{array}{l}\text { Diesel generators (one new at } 40 \mathrm{~kW} \text { and two existing at } 65 \mathrm{~kW} \text { ), a 35- } \\
\text { kW RivGen hydrokinetic turbine, two } 18-\mathrm{kW} \text { wind turbines, and 53-75 } \\
\text { kWh of BES }\end{array}$ \\
\hline Scenario 3 (two RivGen turbines) & $\begin{array}{l}\text { Diesel generators (one new at } 40 \mathrm{~kW} \text { and two existing at } 65 \mathrm{~kW} \text { ), two } \\
\text { 35-kW RivGen hydrokinetic turbines, and 53-75 kWh of BES }\end{array}$ \\
\hline Scenario 4a (medium wind and solar PV) & A $50-\mathrm{kW}$ wind turbine, a 50-kW solar PV system, and $53-75 \mathrm{kWh}$ of BES \\
\hline Scenario 4b (high wind) & A $100-\mathrm{kW}$ wind turbine and $53-75 \mathrm{kWh}$ of BES \\
\hline $\begin{array}{l}\text { Scenario } 5 \text { (thermal solutions in a high- } \\
\text { renewable-energy-contribution situation) }\end{array}$ & $\begin{array}{l}\text { Heat pumps, a solar thermal for heating applications (likely only } \\
\text { residential application rather than commercial in scale), and electric } \\
\text { thermal stoves }\end{array}$ \\
\hline $\begin{array}{l}\text { Scenario 6a (develop infrastructure to sell } \\
\text { electricity to lodges) }\end{array}$ & $\begin{array}{l}\text { Three diesel generators at } 65 \mathrm{~kW} \text { each, } 1.2-\mathrm{kW} \text { solar } \mathrm{PV} \text {, six } 2-\mathrm{kW} \text { wind } \\
\text { turbines, a biomass boiler, a heat recovery loop from the powerhouse } \\
\text { to water treatment facility/water tank/store, solar thermal for heating } \\
\text { applications, greenhouse }\end{array}$ \\
\hline $\begin{array}{l}\text { Scenario } 6 \mathrm{~b} \text { (same as } 6 \text { a but with more } \\
\text { solar PV) }\end{array}$ & $\begin{array}{c}\text { Diesel generators (two existing at } 65 \mathrm{~kW} \text { ), a } 35-\mathrm{kW} \text { RivGen hydrokinetic } \\
\text { turbine, and } 53-75 \mathrm{kWh} \text { of BES }\end{array}$ \\
\hline $\begin{array}{l}\text { Scenario } 7 \text { (phased approach with a mix of } \\
\text { all solutions) }\end{array}$ & $\begin{array}{l}\text { Diesel generators (one new at } 40 \mathrm{~kW} \text { and two existing at } 65 \mathrm{~kW} \text { ), a 35- } \\
\text { W RivGen hydrokinetic turbine, two } 18-\mathrm{kW} \text { wind turbines, and 53-75 } \\
\text { kWh of BES }\end{array}$ \\
\hline
\end{tabular}

Further discussion with the group sought a better understanding of how these potential scenarios align with village interests. In terms of population size and possible load-growth scenarios, community representatives Karl Hill and Dave Hostetter re-emphasized that the community is generally happy with the current village population size, which they feel is environmentally sustainable. They also indicated that they would like to include a little more solar PV in the scenarios, because this technology is relatively proven and has been used successfully on Dave's house for some time. There was discussion 
about whether trackers on solar panels are useful in Alaska. NREL staff conveyed that geographical diversification of solar panels may be a good idea to help eliminate, for example, a single cloud taking production out. Responsive load was discussed, with the possibility to dump excess loads from renewable energy into residential electric thermal stoves (bricks); Karl indicated that responsive load might make most sense in community buildings. The opportunity to use heat pumps was also discussed. 


\section{Discussion and Next Steps}

Igiugig is a well-organized, rural, Alaskan community with a leadership team that has broad community support. The use of consensus-based decision making is one tangible example of how the leadership team actively invokes and promotes community-focused thinking. The NREL team observed anecdotal evidence of how this approach is strengthening the community, including active participation in the vision exercise, a student-hosted fundraiser dinner at the school, a clean and organized garbage landfill, and well-maintained roads and buildings. The consensus approach seems especially promising for a large initiative because it suggests that, when the community supports it, the initiative can progress quickly and is also more likely to have the sustainable, long-lasting support it needs to overcome challenges along the way.

Igiugig has wind, solar, and river hydrokinetic resources readily available within the community. Wind has been shown to be a promising energy resource in the region and has been integrated into microgrids around the state. Recently, the community has had mixed success with wind energy. The largest setbacks in this area have been associated with the deployment and failure of vertical-axis wind turbines, which have had limited global commercial success compared to horizontal-axis wind turbines. The community has had relative success with the horizontal-axis turbines that have been deployed, and so it is reasonable to look more closely at how wind energy can help Igiugig meet its energy goals.

Solar has previously been viewed as inappropriate for Alaska because of the long, dark winters at high latitudes. More recently, however, as the cost of solar panels has come down and fossil-fuel energy prices around the state have risen, the economics of solar energy have improved, and cost-effective solar projects are being installed around the state. Considering that economic activity in Igiugig peaks during the summer sportfishing season, solar energy could prove to be a valuable supplement to the electrical system.

Igiugig has been a test site for two different river hydrokinetic devices, and the installation of ORPC's RivGen device during the summer of 2019 is the beginning of a third project to demonstrate this technology's reliability, cost, and environmental interactions. Igiugig's river resource is fairly unique in Alaska because it is available year-round, and debris concerns are somewhat reduced because it is at the lake source (i.e., fewer logs, branches, and stumps than other sites, though ice is still an issue). This makes Igiugig's riverine resource especially intriguing because it has the potential to provide reliable, base-load power for months at a time - as long as the turbines are installed and operating. At the same time, river hydrokinetic technology is an emerging (precommercial) technology, and so, the community should be prepared for challenges in the process of pursuing this option and should be careful to protect itself from the risks associated with emerging technology demonstration projects.

A preliminary investigation of this diverse resource mix suggests that Igiugig could achieve very high levels $(70 \%$ or more) of annual renewable energy generation. Combining this mix of resources to achieve this level of renewable energy would be a cutting-edge project. A critical first step in pursuing this path is completing energy-efficiency and conservation measures, which has been a primary focus for many years. It is also important to assess the mix of energy assets (generation and storage) that best meets the community's needs, goals, and budget. The early steps taken in a community's gridmodernization efforts determine which options are economical at later stages, so a technical and economic analysis now can guide the most promising path forward. These analyses are most accurate and informative when they are based on realistic technology performance and cost data. As the RivGen project continues to generate these kinds of data, we will be better prepared to evaluate the technology's long-term viability and identify research areas that would improve it. 
If these projects are successful, the lessons learned and technologies developed could be valuable for other microgrids around the world. Igiugig's unique resource mix make it an ideal site for this work, and the community's organizational strength makes it an ideal partner for this ground-breaking work.

Ongoing support for technical assistance to manage and address technical challenges along the way will maximize the probability of project success. 


\section{Appendix A. Site Visit Agenda}

Meeting Objectives:

Village Marine Energy Case Study: Igiugig, Alaska

Site Visit Agenda

January 23-25, 2019

- Listen to community members to identify the long-term needs, goals, and vision for the next 10 20 years

- Collect data to better understand energy loads and other power requirements

- Brainstorm renewable energy scenarios with the potential to meet these goals, discussing the pros and cons of each from both the local and technical perspective

- Develop and prioritize a set of scenarios for more detailed follow-on analysis.

- Attendees: Igiugig, National Renewable Energy Laboratory (NREL), Intergrid, Ocean Renewable Power Company (ORPC), University of Alaska Fairbanks (UAF), Alaska Energy Authority (AEA), Bristol Bay Native Corporation, Bristol Bay Native Association, Borough

Table A-1. Agenda for Day One - Wednesday, January 23, Noon-4 p.m.

\begin{tabular}{|c|c|c|c|c|}
\hline Time & Agenda Item & Specifics & Nominal Lead & Location \\
\hline Noon & Arrival in Igiugig & Arrival via air charter & $\begin{array}{l}\text { External } \\
\text { attendees }\end{array}$ & Village \\
\hline 12:30 p.m. & Introductions & $\begin{array}{l}\text { Initial introductions, guests bring } \\
\text { sack lunch, and settling in }\end{array}$ & AlexAnna/Karl & Village \\
\hline 1:30 p.m. & Tour of village & Tour of Igiugig facilities & AlexAnna/Karl & Village \\
\hline 2:30 p.m. & Data collection & $\begin{array}{l}\text { Collect data to fill gaps (e.g., } \\
\text { furnaces) }\end{array}$ & Levi, Rob & Village \\
\hline 5:00 p.m. & Dinner & $\begin{array}{l}\text { NREL brings sandwiches for all } \\
\text { guests and a few IVC staff }\end{array}$ & Levi, Rebecca & Village \\
\hline
\end{tabular}

Table A-2. Agenda for Day Two - Thursday, January 24, 10 a.m.-6 p.m.

\begin{tabular}{|c|c|c|c|c|}
\hline Time & Agenda Item & Specifics & Nominal Lead & Location \\
\hline 9:00 a.m. & $\begin{array}{l}\text { Breakfast on } \\
\text { own }\end{array}$ & $\begin{array}{l}\text { Guests to make their own } \\
\text { breakfast }\end{array}$ & - & - \\
\hline 10:00 a.m. & $\begin{array}{l}\text { Welcome \& } \\
\text { introductions }\end{array}$ & Attendee introductions & AlexAnna/Karl & Hangar \\
\hline 10:15 a.m. & $\begin{array}{l}\text { Igiugig Village } \\
\text { Council } \\
\text { presentation }\end{array}$ & $\begin{array}{l}\text { Presentation on progress, goals, } \\
\text { and resources w/question and } \\
\text { answer }\end{array}$ & AlexAnna/Karl & Hangar \\
\hline 10:45 a.m. & $\begin{array}{l}\text { NREL } \\
\text { presentation }\end{array}$ & $\begin{array}{l}\text { Review of project goals and } \\
\text { resources (e.g., data, funding, } \\
\text { tools) w/question and answer }\end{array}$ & Levi & Hangar \\
\hline 11:15 a.m. & $\begin{array}{l}\text { AEA } \\
\text { presentation }\end{array}$ & AEA perspectives & Josh & Hangar \\
\hline 11:30 a.m. & $\begin{array}{l}\text { Intergrid } \\
\text { presentation }\end{array}$ & Intergrid perspectives & Rob & Hangar \\
\hline
\end{tabular}




\begin{tabular}{|l|l|l|l|l|}
\hline Time & Agenda Item & Specifics & Nominal Lead & Location \\
\hline $\mathbf{1 1 : 4 5}$ a.m. & ORPC & ORPC perspectives & Monty & Hangar \\
\hline Noon & Lunch & $\begin{array}{l}\text { lgiugig Village to host a working } \\
\text { lunch }\end{array}$ & AlexAnna/Karl & Hangar \\
\hline $\mathbf{1 : 0 0}$ p.m. & $\begin{array}{l}\text { UAF } \\
\text { presentation }\end{array}$ & UAF perspectives & Jeremy & Hangar \\
\hline $\mathbf{1 : 1 5}$ p.m. & Group discussion & $\begin{array}{l}\text { Strategic planning discussions } \\
\text { (long-term-vision exercise) }\end{array}$ & Eliza & Hangar \\
\hline $\mathbf{3 : 0 0}$ p.m. & Group discussion & $\begin{array}{l}\text { Brainstorm renewable energy } \\
\text { scenarios }\end{array}$ & Greg & Hangar \\
\hline $\mathbf{4 : 0 0}$ p.m. & Group discussion & $\begin{array}{l}\text { Identify and prioritize scenarios for } \\
\text { detailed economic analysis }\end{array}$ & Levi & Hangar \\
\hline $\mathbf{5 : 0 0}$ p.m. & Group discussion & $\begin{array}{l}\text { Summarize, wrap-up, and steps } \\
\text { forward }\end{array}$ & Levi & Hangar \\
\hline $\mathbf{6 : 0 0}$ p.m. & Dinner & $\begin{array}{l}\text { Kvichak Café, student-run café, } \\
\text { open for dinner }\end{array}$ & AlexAnna/Karl & Hangar \\
\hline
\end{tabular}

Table A-3. Agenda for Day Three - Friday, January 25, 9 a.m.-Noon

\begin{tabular}{|c|c|c|c|c|}
\hline Time & Agenda Item & Specifics & Nominal Lead & Location \\
\hline 8:00 a.m. & $\begin{array}{l}\text { Breakfast on } \\
\text { own }\end{array}$ & $\begin{array}{l}\text { Guests to make their own } \\
\text { breakfast }\end{array}$ & - & - \\
\hline 9:00 a.m. & $\begin{array}{l}\text { School } \\
\text { presentation }\end{array}$ & $\begin{array}{l}\text { Presentation on renewable energy } \\
\text { activities and scenarios }\end{array}$ & Levi & School \\
\hline 11:30 a.m. & Departure & Return via air charter & $\begin{array}{l}\text { External } \\
\text { attendees }\end{array}$ & Village \\
\hline
\end{tabular}




\section{Appendix B. Workshop Attendee List}

Table B-1. Workshop Attendee Information

\begin{tabular}{|c|c|c|}
\hline Name & Affiliation & Email \\
\hline AlexAnna Salmon & $\begin{array}{l}\text { Igiugig Village Council (IVC) } \\
\text { (president) }\end{array}$ & alexannasalmon@gmail.com \\
\hline Karl Hill & $\begin{array}{l}\text { IVC (administrator and council } \\
\text { vice president) }\end{array}$ & Karlhill907@yahoo.com \\
\hline Levi Kilcher & $\begin{array}{l}\text { National Renewable Energy } \\
\text { Laboratory (NREL) }\end{array}$ & Levi.Kilcher@nrel.gov \\
\hline Rebecca Green & NREL & Rebecca.Green@nrel.gov \\
\hline Eliza Hotchkiss & NREL & Eliza.Hotchkiss@nrel.gov \\
\hline Greg Stark & NREL & Greg.Stark@nrel.gov \\
\hline Patty Heyano & $\begin{array}{l}\text { BBNA (program development } \\
\text { director) }\end{array}$ & pheyano@bbna.com \\
\hline Jayne Bennett & $\begin{array}{l}\text { Bristol Bay Native Association } \\
\text { (renewable energy coordinator) }\end{array}$ & jbennett@bbna.com \\
\hline Josh Craft & Alaska Energy Authority & jcraft@akenergyauthority.org \\
\hline Randy Alvarez & Igiugig resident & RANDY99613@Live.com \\
\hline Jeremy Vandermeer & $\begin{array}{l}\text { Alaska Center for Energy and } \\
\text { Power }\end{array}$ & jbvandermeer@alaska.com \\
\hline Dave Hostetter & $\begin{array}{l}\text { Igiugig resident (powerplant } \\
\text { and water plant operator) }\end{array}$ & Igiugig_repair_shop@hotmail.com \\
\hline Brian Hirsch & $\begin{array}{l}\text { Deer Stone Consulting } \\
\text { (attending on behalf of } \\
\text { Southwest AK Municipal } \\
\text { Conference \& Lake and Pen } \\
\text { Borough) }\end{array}$ & brian@deerstoneconsulting.com \\
\hline Monty Worthington & $\begin{array}{l}\text { Ocean Renewable Power } \\
\text { Company }\end{array}$ & mworthington@orpc.com \\
\hline Sandy Alvarez & $\begin{array}{l}\text { IVC (village electric and director } \\
\text { of accounting) }\end{array}$ & sjalvarez@aol.com \\
\hline Danica Wilson & Lake \& Pen Borough & CDC@lakeandpen.com \\
\hline Christina Salmon & IVC & christinasalmon@hotmail.com \\
\hline Rob Wills & Intergrid & RWills@intergrid.us \\
\hline Simeon Zackar & Igiugig student & - \\
\hline Aiden Wassillie & Igiugig student & - \\
\hline Jeff Bringhurst & Igiugig resident & Jeffbringhurst22@gmail.com \\
\hline Sheryl Wassillie & IVC & siwassillie@gmail.com \\
\hline Daniel Cheyette & Bristol Bay Native Corporation & dcheyette@bbnc.net \\
\hline Alicia Zackar & IVC & alicia_zackar17@live.com \\
\hline
\end{tabular}




\section{Appendix C. Igiugig Energy History and Goals}

The following content was developed by the Igiugig Village Council as a handout for the workshop to inform and provide background for the discussions.

\section{Progress}

- Comprehensive community planning in 2000

- 2008 Electric Power Research Institute Study

- Power plant upgrade in 2011

- Completed bathymetric profile of Kvichak and permitting for hydrokinetic project in 2012-2013

- Completed a 1-year meteorological study through Lake and Pen Borough and Knight-Piesold in 2012

- Other meteorological studies being conducted by the University of Alaska Anchorage and Stanford University through Moore Foundation

- Installed six horizontal-axis wind turbines (including privately owned) with varying degrees of success

- Installed and tested a variety of vertical-axis wind turbines that are not extremely successful thus far

- Tested two designs of hydrokinetic devices; RivGen proved viable, the other design did not

- Successfully deployed and retrieved the RivGen with the Ocean Renewable Power Company in 2014 and 2015 with plenty of lessons learned from each.

\section{Goals}

We hope that our discussion will help to clarify and focus our goals after this set of meetings, which include:

- Extending heat recovery loop from powerhouse

- Overhauling existing diesel generators

- Utilizing solar photovoltaics and thermal energy

- Purchasing Native allotment for wind turbines

- Installing renewable energy systems at clinic

- Lowering diesel dependency for electricity and heat

- Combining a variety of renewable energy sources to provide a high contribution of renewable energy and allow "diesels off," which is critical to meeting the community's renewable energy goals 
- Completing grid integration of renewable energy to our diesel generation plant grid and energy storage

- Achieving energy self-sufficiency.

\section{Resources}

The following is a list of "resources" the community identified that they feel are valuable to their energy vision:

- Construction and fabrication personnel

- Crane, loaders, excavators, dozers, trucks, camp facilities, other heavy equipment

- Flexifloat barge

- Push boat

- Safety boat. 


\section{Appendix D. Community Vision Exercise}

The visioning exercise was done in two groups: a "local community group," and an "external stakeholders group." Both groups identified items across three categories: challenges, vision, and solutions.

\section{Local Community Group}

Based on the workshop, the following ideas were identified by the community in each category. Number of votes are in parentheses.

\section{Challenges}

1. Regional mining (4)

2. Shortage of personnel and expertise in the community (2)

3. Lack of housing, especially affordable and energy efficient (2)

4. High cost of fuel, energy, and food

5. Limited funding; funding that exists is competitive, requiring time and effort to write and manage grants

6. Village population has more youth than elders

7. Infrastructure is sized to accommodate the summer boom, which is oversized for most of the year, and residents pay for the upkeep of the systems

8. Land is swampy and access to water typically means higher costs; water is smelly

9. Remote location means expensive transportation, which translates into higher costs for goods and food

10. Power system frequency fluctuations

11. Expensive and limited communications networks

12. Water distribution in a small population spread over a relatively large area is challenging.

13. Runway maintenance, expansion, dust, and poor air quality in the village as a result of the airport

14. Environmental impact studies are time-consuming and expensive

15. Lack of a police force

16. Pressure from sportfishing; sportfishing is an important source of revenue for the community, but it also brings challenges

17. Climate change (changes in ice breakup timing, temperatures, precipitation, and so on)

18. Inaccurate census data means full population is not recognized, thus less funding is available

19. Land ownership and management: leases, consolidation, allotments, traditional management practices

20. Big Mountain is a sacred site, which is contaminated by polychlorinated biphenyls, Diesel Range Organics, lead, and so on and is thought to be causing cancer because it's a harvest location for traditional subsistence practices

21. Crowded public boat ramp causes conflict during fishing season

22. No Native control over water rights

23. Trespassing on Native lands

24. Low number in workforce

25. Access to markets for economic stability and diversification

26. High turnover, fewer opportunities for training and building capacity

27. Loss of Native language

28. Need for a cultural community center 
29. Loose dogs

30. Substance abuse

31. A lot of studies, analyses, and reports, but no action plan to help with implementing and identifying funding streams

32. River bank erosion

33. No clear path for how to build for the future.

\section{Vision}

1. Careful consideration of regional mining (3)

2. Living by cultural values, invigorating the Yup'ik dance group, reviving the Yup'ik language, and establishing cultural tourism (2)

3. Establish a community children want to return to after attending college or university (2)

4. Running a rock quarry for economic development (1)

5. Achieve financial independence

6. Affordable energy

7. Tribal school that teaches traditional skills

8. Become a regional leader as a test bed for alternative technologies

9. Create a culture of entrepreneurship

10. Continue drinking river water (protect water resources)

11. Develop a locally based airline

12. Build a Iliamna subdivision

13. Complete road to Floatplane Lake and Kaskanak Lake

14. Sustain salmon industry and culture

15. Affordable housing (e.g., tiny U.S. Department of Housing and Urban Development [HUD] homes)

16. Build cultural center

17. Build adequate transportation facilities (runway, boat harbors, roads)

18. Establish a booming greenhouse

19. Run sport fishing lodges

20. Operate a tribal court

21. Develop conservation easements

22. Acquire several in-town Native allotments (to be returned to tribe).

\section{Solutions}

1. Deploy a combination of renewable energy and energy storage (2)

2. Affordable, energy-efficient housing that is attractive (2)

3. Continue an annual local food challenge to encourage food security and sustainability, as well as health (1)

4. Involve youth in a long-term vision to create a community that they will be proud of and to which they will want to return (1)

5. Creative leasing and holding escrow to meet community vision (1)

6. Start a water bottling business (1)

7. Develop a workforce and create a team to manage utilities in the village

8. Hire a sportfishing trespassing officer

9. Continue to encourage the use of Native language and promote our culture through targeted programs and emphasis by leaders. 
10. Develop a comprehensive master plan for the energy sector, including the development of more solar and heat pumps to test in southwestern Alaska

11. Build net-zero energy buildings

12. Reclaim Big Mountain with reclamation projects being funded by the government or by the polluters themselves

13. Share Yup'ik culture with visitors by organizing weekly performances at nearby lodges and continue to improve the annual cultural camp

14. Celebrate successes on a regular basis

15. Continue to develop partnerships, especially with technical experts and private organizations, such as Conservation International, New Venture Fund, Wild Ark, and so on

16. Develop a strategic plan for funding opportunities

17. Initiate flight simulator training and other types of training

18. Build a cultural center with stage.

\section{External Stakeholders Group}

Based on the workshop, the following ideas were identified by the external partners in each category. Number of votes are in parentheses.

\section{Challenges}

Sector $=$ Infrastructure

1. Internet (2)

2. Transient loads (2)

3. Diesel generator sizing

4. Equipment disposal

Sector $=$ Social and Cultural

1. Community size (3)

2. Isolated (1)

3. Cultural heritage (1)

4. Outmigration

Sector $=$ Environmental

1. Oil spill concerns (2)

2. Salmon run (2)

3. Regional mining (1)

4. Climate change

5. Icing

Sector $=$ Economic

1. Transport logistics (2)

2. Economics (2)

3. Project success (2)

4. Financing (1)

5. Seasonal workforce (1)

6. Jobs. 


\section{Vision Priorities}

- Holistic community plan and execution to create a resilient and sustainable community

- Energy self-sufficiency

- Minimize environmental impact

- Cultural values

- Economic sustainability

- Minimize diesel.

\section{Solution Priorities}

- Diverse renewable energy microgrid

- Local/regional workforce

- Negotiate access to fiber-optic, high-speed internet

- Involve partners (e.g., Rob Wills with Intergrid). 